\title{
TISKANI ČASOSLOVI ANDRIJE PALTAŠIĆA I DOBRIĆA DOBRIĆEVIĆA (BONINUS DE BONINIS) I NJIHOVA LIKOVNA OPREMA
}

Ugledna talijanska povjesničarka knjige s oksfordskog sveučilišta, Cristina Dondi, objavila je 2016. opsežnu monografiju o časoslovima Blažene Djevice Marije tiskanima u Italiji do 1500. godine (DONDI 2016). U tom iscrpnom pregledu ranih tiskanih oficija u Italiji opisano je i nekoliko izdanja koja se više ili manje izravno tiču hrvatske kulturne sredine toga vremena. Autorica je opisala i tiskane oficije objavljene u štamparijama dvojice tiskara hrvatskoga podrijetla: Andrije Paltašića u Veneciji i Dobrića Dobrićevića (Boninus de Boninis) u Veroni. Na te ćemo se tiskane oficije, slabo poznate hrvatskoj stručnoj publici, detaljnije osvrnuti u uvodnom dijelu ovoga rada. Težište razmatranja bit će, međutim, na časoslovima Dobrića Dobrićevića, tiskanima u Lyonu, a posebice na njihovoj likovnoj opremi. Naime, Dobrićević je 1481. u Veroni, koliko je poznato, tiskao prvi oficij uopće ilustriran drvorezima, da bi poslije Lyonu objavio još tri izdanja oficija ilustrirana $u$ »francuskom« stilu, kojega su značajke prihvatili i neki venecijanski tiskari tog vremena. On je prepoznatljiv i u likovnoj opremi tzv. Dubrovačkog molitvenika, tiskanog 1512. kod Giorgia Rusconija u Veneciji.

Ključne riječi: Dobrić Dobrićević (Boninus de Boninis), Andrija Paltašić, Nicolaus Jenson, ilustracije oficija Blažene Djevice Marije

\section{NIKOLAUS JENSON, ANDRIJA PALTAŠIĆ I POČECI TISKANIH OFICIJA}

Koliko je poznato, prvi tiskani Officium Beatae Marie Virginis secundum usum Romanum uopće objavio je 1474. u Veneciji tiskar francuskoga podrijetla Nicolaus Jenson (DONDI 2016: 7). ${ }^{1}$ Bilo je to samo pet godina nakon

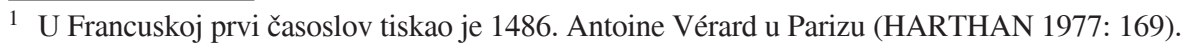


zapisa u znamenitom dokumentu mletačkog senata, koji započinje rečenicom Inducta est in hanc nostram inclytam civitatem ars imprimendi libros... (Uvedeno je u ovaj naš slavni grad umijeće tiskanja knjiga) (POZZA 1983: 18). Potražnja za malim, džepnim časoslovima (oficijima ili molitvenicima) namijenjenima širem krugu laičkih i crkvenih korisnika bila je takva da su ubrzo uslijedila brojna tiskana izdanja iz radionica drugih venecijanskih i talijanskih tiskara. ${ }^{2}$ Sam Jenson objavio je u Veneciji četiri vrlo slična izdanja u dvije godine. Samo četiri godine nakon Jensona, 20. travnja 1478., Andrija Paltašić Kotoranin, koji je tek započeo tiskarsku karijeru u gradu na lagunama, tiskao je svoje izdanje časoslova koje se u velikoj mjeri oslanjalo na Jensonov predložak. ${ }^{3}$ Paltašić je, naime, »kopirao « treće Jensonovo izdanje iz oko $1475 .{ }^{4}$ Sadržaj časoslova obuhvaća kalendar i uobičajene molitvene odsječke: službu Blažene Djevice Marije, misu u čast Blažene Djevice Marije, sedam pokorničkih psalama, litanije, posebne molitve, Atanazijevo vjerovanje (Symbolum Athanasii), službu za pokojne, službu sv. Križa, službu Duha Svetoga i molitvu sv. Anzelma.

Premda je Jenson u Veneciju došao iz Francuske, kao model za svoja tiskana izdanja oficija on nije preuzeo francuske rukopisne predloške, već talijanske, bliske njegovim neposrednim korisnicima i kupcima. Dakako, oni su očekivali da tiskani časoslovi što više nalikuju uvriježenim rukopisnim primjercima (DONDI 2016: 66). Stoga su tiskani oficiji imali sličan raspored sadržaja kao i rukopisni, u pravilu su bili vrlo malog, džepnog formata, često tiskani na pergameni, pri čemu su u slogu ostavljana prazna mjesta za ručno unošenje svečanih inicijala i velikih početih slova. Tako su, primjerice, u svakom od pet sačuvanih primjeraka prvoga Jensonova izdanja iz 1474. (svi tiskani na pergameni) ručno uneseni svečani inicijali, dok su veća početna slova kaligrafski crtana ili slikana (DONDI 2016: 243-247). Isto vrijedi i za njegova kasnija izdanja, pri čemu je svaki primjerak ručno obogaćen s više ili manje likovnih dodataka. ${ }^{5} \mathrm{U}$ primjerku Jensonova oficija koji se čuva u

2 Za osnovne informacije o značajkama i razvoju tog tipa molitvene knjige v. HARTHAN 1977; WIECK 1988; DONDI 2016. Na hrvatskom jeziku v. PANTELIĆ 1981; TANDARIĆ 1981.

3 Andrija Paltašić (Paltasichis, oko 1440. - oko 1500.), koji se često naziva prvim hrvatskim ili prvim južnoslavenskim tiskarom, aktivan je u Veneciji od 1476. do 1493., v. NEEDHAM 1998: 171, 175; MILOŠEVIĆ 1994.

${ }^{4}$ Paltašić je prenio neke Jensonove omaške u pisanju imena svetaca, druge je ispravio (npr. S. Nicomedis u Nicodemis), neke je i sam napravio (npr. S. Zeuerini u S. Senerini itd.).

5 Svaki je sačuvani primjerak drugačiji. Usp. TONIOLO 2008: 122-128, 159. Primjerak Jensonova časoslova koji se može konzultirati on-line čuva se u Münchenu, Bayerische Staatsbibliothek, v. Jenson, Horae. 
Knjižnici Muzeja Correr u Veneciji, primjerice, mnogi su inicijali kaligrafski ukrašeni crvenom i plavom tintom. ${ }^{6}$

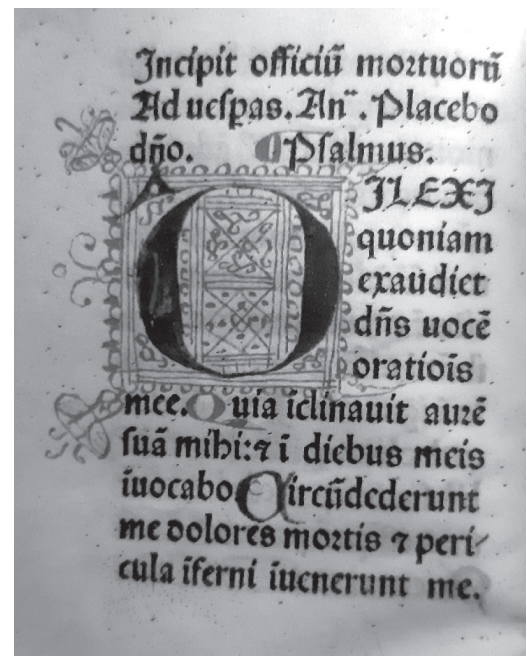

Sl. 1. Kaligrafski ukrašen inicijal, Oficij BDM, Nicolaus Jenson, Venecija, oko 1475.

Venecija, Biblioteca del Museo Correr.

Fig. 1. Calligraphic initial, Office of the BVM, Nicolaus Jenson, Venice, around 1475. Venice, Biblioteca del Museo Correr.

Na kraju knjižice otisnut je prigodni epigram Raffaela Zovenzonija, istarskog humanista i pjesnika podrijetlom iz Trsta, koji je kod Jensona neko vrijeme radio kao korektor. ${ }^{7}$ Epigram koji glasi Nicoleos (!) Jenson gallorum / gloria miro / Ingenio impressit virginis / officium (Nikolaus Jenson, slava Francuske, čudesnim je umijećem tiskao Djevičin oficij), jasno odražava divljenje suvremenika nad činjenicom da je tiskar u sićušnom formatu koji stane na dlan ruke, ostvario zadivljujuću ljepotu tiskane knjige koja je zapanjila ondašnje korisnike, a tako je sve do danas.

Isto bi se moglo reći i za Paltašićevo izdanje oficija, od kojeg su poznata četiri primjerka. ${ }^{8} \mathrm{U}$ pregledanom primjerku iz knjižnice Muzeja Correr u

6 Venecija, Mus. Correr, M 1 Inc. (DONDI 2016: br. 5). U eksplicitu (kolofonu) časoslova nema datuma, no Dondi smatra da je tiskan oko 1475.

7 Bibliografske reference o njemu vidi u DONDI 2016: 10. Dondi smatra da je Zovenzonius možda bio naručitelj tog izdanja oficija (v. DONDI 2016: 259).

8 Po jedan se primjerak Paltašićeva izdanja oficija nalaze u Cambridgeu i Veneciji, a dva u Parizu. Za opise primjeraka v. DONDI 2016: 275. 
Veneciji ${ }^{9}$ ručno su slikani svečani inicijali na počecima glavnih dijelova časoslova. Prema tadašnjem običaju, tiskar je u tekstu ostavljao prazna mjesta za inicijale, koji su potom, najčešće prema želji kupca, odnosno vlasnika, unošeni ručno. Na početku službe Blažene Djevice Marije (sadašnji f. 7r) naslikan je figuralni inicijal $D$ s likom Bogorodice (kojem je oštećen gornji sloj boje i pozlate); na početku pokorničkih psalama (sadašnji f. 89r) naslikan je inicijal $D$ s likom kralja Davida u poprsju; na početku službe za pokojne (sadašnji f. 119r) naslikan je inicijal $D$ s lubanjom; na početku službe sv. Križa (sadašnji f. 172r) naslikan je inicijal $D$ s križem; na početku službe Duha Svetoga (sadašnji f. 177r) naslikan je inicijal $D$ s golubom kao simbolom Duha Svetoga.

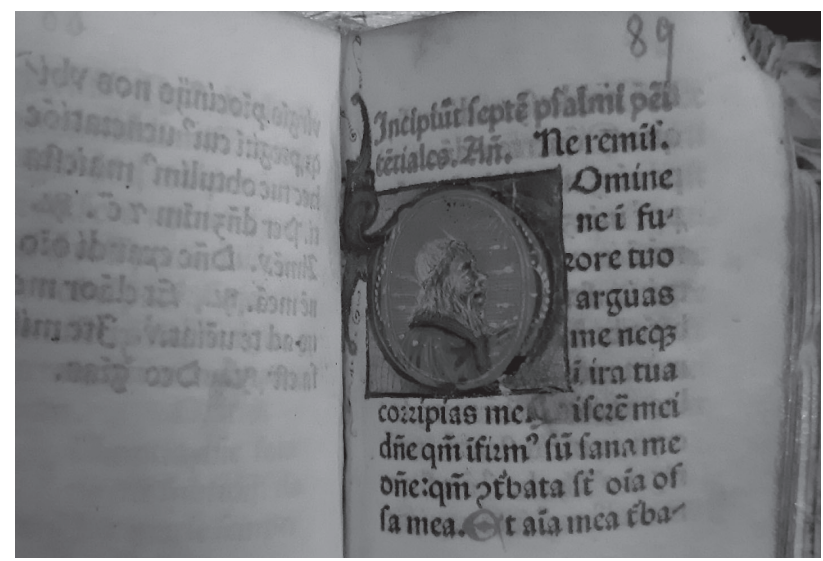

S1. 2. Inicijal s likom kralja Davida, Oficij BDM, Andrija Paltašić, Venecija, 1478. Venecija, Biblioteca del Museo Correr.

Fig. 2. Initial with an image of King David, Office of the BVM, Andrija Paltašić, Venice, 1478. Venice, Biblioteca del Museo Correr.

Stilske značajke oslikanih figuralnih inicijala s pozlaćenom pozadinom i bočnim ukrasnim povijušama odgovaraju, čini mi se, više firentinskom nego mletačkom sitnoslikarstvu toga vremena. ${ }^{10}$ Oblikovanje inicijala kojima po-

\footnotetext{
${ }^{9}$ Primjerak Paltašićeva izdanja oficija koji se čuva u venecijanskom Muzeju Correr (sign. M9 $I N C$ ), a prethodno se nalazio u zbirci Emmanuelea Cicogne, tiskan je oblom goticom na pergameni dimenzija $78 \times 51 \mathrm{~mm}$. Knjižica je defektna: nedostaje joj početak s najvećim dijelom kalendara koji počinje tek od kolovoza, s time da nedostaje i prvi dio studenog, a mnogim su listovima glodavci pojeli gornji desni ugao.

${ }^{10}$ Dondi (2016: 280) smatra da su inicijali slikani u venecijanskom stilu. Međutim, pažljivije usporedbe usmjeravaju atribuciju prema firentinskom sitnoslikarstvu posljednje četvrtine 15. stoljeća. Usp. osobito inicijal s Bogorodicom i djetetom u ovom tiskanom časoslovu i u
} 
činju glavna poglavlja knjige, s umetanjem navedenih ikonografskih motiva, uobičajeno je za likovno skromnije opremljene primjerke rukopisnih i tiskanih oficija toga doba. ${ }^{11}$

Paltašić je, dakle, nakon Jensona bio drugi tiskar u Veneciji koji se odlučio na izdavanje tiskanog oficija. Je li nakon ovoga objavio još koje izdanje te popularne i tražene molitvene knjižice, nije poznato. Jednako tako ne znamo jesu li primjerci njegova oficija dospijevali u jadransku $\mathrm{Hr}$ vatsku. Činjenica da se u kalendaru nalaze blagdani sv. Dujma, sv. Donata, sv. Krševana i sv. Ivana Trogirskog govorila bi u prilog pretpostavci da se računalo i s korisnicima iz dalmatinskih komuna. ${ }^{12} \mathrm{U}$ svakom slučaju, nakon njega slijedio je niz mletačkih i drugih talijanskih tiskara koji su u svoje tiskarske programe uključili časoslove. U njih su ubrzo ušle drvorezne ilustracije.

\section{2. ČASOSLOVI DOBRIĆA DOBRIĆEVIĆA}

\subsection{Oficij Blažene Djevice Marije tiskan u Veroni 1481.}

Drvorezne ilustracije u tiskanom časoslovu prvi je upotrijebio upravo Dobrić Dobrićević (ponekad mu se ime pojavljuje kao Dobruško Dobrić, lat. Boninus de Boninis; Lastovo, oko 1457. - Treviso, 1528.). ${ }^{13}$ Poznato je da su počeci Dobrićevićeve djelatnosti u tiskarstvu povezani s Andrijom Paltašićem. Zajedno s njim Dobrićević je u ožujku 1478. izdao Laktancijevo djelo De divinis institutionibus adversus gentes, pri čemu je možda svjedočio i pripremama za tisak Paltašićeva oficija. Ubrzo nakon toga Dobrićević postaje samostalan tiskar u Veroni.

rukopisnom časoslovu iz Bostona (Boston Public Library MS q Med. 136) koji opisuje F. MANZARI (2016: 288). Bostonski primjerak časoslova oslikao je između 1470. - 1480. Antonio di Niccolò di Domenico u Firenci.

${ }^{11} \mathrm{Za}$ usporedbu podsjećam na dva nešto bogatije oslikana hrvatska rukopisna oficija iz 15. stoljeća u čijim se inicijalima, osim spomenutih motiva, pojavljuju i likovi svetaca: Akademijin dubrovački molitvenik i Vatikanski hrvatski molitvenik (CVETNIĆ 2004; PRIJATELJPAVIČIĆ 2011: 220-239). U jedinom primjerku hrvatskog oficija iz 15. stoljeća tiskanog latinicom, koji se čuva u Vatikanu, nema oslikanih inicijala (DONDI 2016: br. 38). U kasnijem tiskanom glagoljskom oficiju Šimuna Benje Kožića iz 1530. upotrijebljeni su drvorezni inicijali s likom Boga Oca i figurama svetaca.

${ }^{12}$ Svi se ti blagdani nalaze i u kalendaru Jensonova izdanja.

${ }^{13}$ Temeljne podatke za Dobrića i literaturu o njemu vidjeti u: CIONI 1970; JURIĆ 1993; VENEZIANI 1986; PELC 2000. 
Među najranijim Boninusovim objavljenim djelima bio je mali Bogorodičin časoslov tiskan 24. 10. 1481. (DONDI 2016: 300-303). ${ }^{14}$ Struktura teksta uglavnom se poklapa s onom u standardnim talijanskim oficijima, poput Jensonovog i Paltašićevog, s time da Dondi kao njegovu osobitost primjećuje poseban uvod u molitve sv. Grgura ispred službe za pokojne. Dobrićević je u povijesti ranoga tiskarstva istaknut po velikoj pomnji kojom je likovno opremao svoja izdanja kako bi pobudio veće zanimanje zahtjevnije publike. Drvorezne ilustracije važna su sastavnica njegove knjižne opreme, što jasno pokazuje i ovaj časoslov za koji je priređen odgovarajući komplet drvoreznih ilustracija i početnih slova u sitnoslikarskom formatu. To je Dobrićevićevo najranije do sada poznato djelo ilustrirano drvorezima i ujedno prvi časoslov s drvoreznim ilustracijama tiskan u Italiji. ${ }^{15}$

Jedini je poznati primjerak Dobrićevićeva Bogorodičinog časoslova iz 1481. tiskan na pergameni, a čuva se u Gradskoj biblioteci u gradu Bassano del Grappa. ${ }^{16}$ Vrijednost toga primjerka nepoznati je vlasnik nastojao povećati koloriranjem drvoreza i pozlaćivanjem inicijala. Na pet stranica nasuprot najvažnijim poglavljima časoslova bili su otisnuti odgovarajući narativni prikazi s ukrasnim okvirima. Nažalost, dva lista s ilustracijama su istrgnuta, a ostale su sačuvane samo narativne ilustracije otisnute nasuprot početka službe za pokojne, službe Sv. Križa i službe Duha Svetoga. ${ }^{17}$ Osim stranica s pripovjednim prizorima, i stranice s počecima glavnih poglavlja imaju ukrasne drvorezne okvire, pri čemu je tiskar tri takva okvira otisnuo po dva puta. Pored toga, tiskar je pripremio i niz svečanih drvoreznih inicijala s likovima proroka i Boga Oca, životinja i ukrasnih vaza, koji su u sačuvanom primjerku također kolorirani i ukrašeni zlatnom pozadinom. U svemu, za čitavu je knjižicu priređen odgovarajući komplet drvoreznih ilustracija i početnih slova u minijaturnom formatu. Bio je to važan tipografski iskorak koji je otvorio novi spektar mogućnosti u likovnom opremanju tiskanih brevijara i časoslova.

${ }^{14} \mathrm{U}$ njegovu kolofonu stoji: Impressum Veronae per Boninum de Boniniis de Ragusia anno Domini MCCCCLXXXI. XXIIII die octobris. Za iscrpan bibliografski opis v. ISTC: https://data. cerl.org/istc/ih00357600 (16.4.2019.)

${ }^{15}$ Prije gotovo dvadeset godina (PELC 2000.), objavio sam opsežniji rad o ilustracijama u Dobrićevićevim tiskopisima, no ovo izdanje oficija nisam poznavao, premda se spominje u literaturi, posebice talijanskoj (Indice generale degli incunabuli delle biblioteche d'Italia: br. 4819; CASTIGLIONI 1986: 67, 207). Ovom prilikom ispravljam taj propust.

${ }^{16}$ Bassano del Grappa, Museo, Biblioteca Archivio, sign. INC. I. A. 1., dim. $92 \times 70$ mm, oblo gotičko pismo. Tekst je na latinskom jeziku, osim nekoliko molitava na talijanskom s obilježjima venecijanskoga dijalekta.

${ }^{17}$ Prvi list s ilustracijom nedostaje nasuprot stranici s početkom oficija. Na drvorezu je vjerojatno bilo prikazano Navještenje. Drugi list bio je nasuprot stranici sa sedam pokorničkih psalama. Ilustracija je vjerojatno prikazivala motiv Davida pokajnika ili Davida i Bat Šebe. 
Izgled je ilustriranih parova stranica otvorenih od verso jednog i recto sljedećeg lista u Dobrićevićevu oficiju uređen tako da se, gledajući u rastvorenu knjižicu, na stranici lijevo od hrpta nalazi drvorezni uokviren narativni prikaz, a na stranici desno od hrpta početak teksta određene službe s ucrtanim inicijalom i drvoreznim okvirom. ${ }^{18}$ Takvo je tipografsko rješenje neusporedivo bogatije, ali i zahtjevnije za izradu od onoga koji se nalazi u Jensonovim i Paltašićevim oficijima. Zahtjevnijim grafičkim uređenjem Dobrićevićev se časoslov u okvirima mogućnosti knjigotiska bitno približio otmjenije opremljenim rukopisnim predlošcima što je zacijelo i bila tiskareva namjera. Zato se u njegovu pohvalu, jednako kao i za Jensona, može parafrazirati Zovenzonijev epigram: Miro ingenio impressit virginis officium (Čudesnim je umijećem tiskao Djevičin oficij).

O stilskim značajkama ilustracija Dobrićevićeva oficija pisalo se u okviru povijesti sitnoslikarstva u Veroni s posebnim naglaskom na odnosu sitnoslikarâ i tiskarâ u ranom razdoblju drvorezne ilustracije (CASTIGLIONI 1986: 67: 207-208). Naime, predloške za drvoreze izradio je u stilu Mantegnine umjetnosti nepoznati sitnoslikar, a Castiglioni (1986: 67) drži da ti drvorezi podsjećaju na one Francesca dai Librija, jednog od vodećih veronskih sitnoslikara s konca 15. stoljeća. Crtež sićušnih drvoreza krajnje je jednostavan, bez unutrašnjeg sjenčanja, s vidljivom težnjom da se oponaša tada sve popularniji tzv. arheološki klasicizam. Ta je težnja svojstvena svim likovnim umjetnostima na području Veneta druge polovice 15. stoljeća. Nažalost, ruka drvorezača nije bila tako vješta kao ruka crtača predloška, a koloriranje je obavljeno vrlo površno. ${ }^{19}$ Castiglioni (1986: 208) ukazuje na nekoliko detalja, poput dekorativne konstrukcije inicijala i ukrasnih kandelabara na drvorezima, koji idu u prilog pretpostavci da sitnoslikar koji je crtao predloške za drvoreze dolazi iz kruga veronske radionice Francesca dai Librija. U svakom slučaju, Dobrićević je za izradu predložaka angažirao dobrog sitnoslikara, možda i samoga Francesca dai Librija, da mu priredi cteže za drvoreze..$^{20}$ Bio je to jedan od mnogih primjera sudjelovanja sitnoslikara u opremanju ranih tiskanih knjiga. Činjenicu da su drvorezi kolorirani a da grbovi u njima nisu ispunjeni znakovima vlasnika Castiglioni tumači u duhu mogućnosti da je koloriranje provedeno već po nalogu tiskara (CASTIGLIONI 1986: 208). Naime, da je kupac naručio koloriranje i pozlaćivanje, vjerojatno bi u grbove dao unijeti i

${ }^{18}$ Knjižica se zbog čvrstog uveza iz konzervatorskih razloga ne smije potpuno otvoriti, tako da je istodobno snimanje dviju susjednih (verso jednog i recto sljedećeg lista) stranica nemoguće.

${ }^{19} \mathrm{G}$. Castigioni piše da su ilustracije sumarno rezane i grubo kolorirane (sommariamente incise e rozzamente dipinte) (CASTIGLIONI 1986: 207).

${ }^{20}$ Francesco dai Libri (1450. - 1503. ili 1506.) bio je otac znamenitog sitnoslikara Girolama dai Librija, jednog od učitelja Julija Klovića. 
svoje heraldičke oznake. Međutim isto je tako moguće da vlasnik nije pripadao plemićkom staležu.

Spomenuti se arheološki klasicizam očituje u ukrasnim okvirima s motivima all'antica, omiljenim u Mantegninom umjetničkom okružju. To su motivi rimske groteske: kandelabri, vaze, putti, fantastična morska bića, dupini, maskeroni, sfinge i sl., koji ovdje nisu puki ukrasi, već posreduju značenja koja im je prisvajanjem poganske simbolike pridalo kršćanstvo, a koja su bila lako razumljiva i prihvatljiva tada suvremenom čitaocu. Tim su kristijaniziranim simbolima pobijeđenoga poganstva dodani simboli životinja čija se značenja nadovezuju na srednjovjekovnu tradiciju moralistički poučne naracije u okviru koje se simboli životinja koriste u prvom redu kao metafore moralno dobrog i moralno lošeg ponašanja, odnosno kao simboli zla i dobra u vječnom sukobu i borbi za čovjekovu dušu. Tako je na jednom, dva puta otisnutom okviru, s lijeve strane u povijuši prikazan majmun, simbol Sotone i tašte ispraznosti materijalnoga svijeta, dok je na desnoj strani srna koja simbolizira dušu predanu vjeri i molitvi.

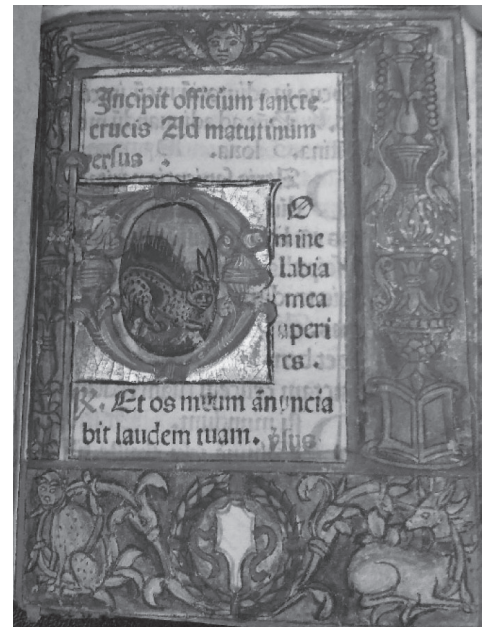

Sl. 3. Stranica s početkom Službe sv. Križa, Oficij BDM, Dobrić Dobrićević (Boninus de Boninis), Verona, 1481. Bassano del Grappa, Museo, Biblioteca Archivio.

Fig. 3. Page with the beginning of the liturgy of the Holy Cross, Office of the BVM,

Dobrić Dobrićević (Boninus de Boninis), Verona, 1481. Bassano del Grappa, Museo, Biblioteca Archivio.

Na sitnoslikarskim ilustracijama Dobrićevićeva molitvenika stapaju se motivi poganske antičke groteske i srednjovjekovne simbolike životinja iz Fiziologa i bestijarija, prožeti kršćanskim značenjima na način koji je odgo- 
varao humanističkom svjetonazoru. Ti su motivi preuzeti iz simboličkog fonda rukopisnih liturgijskih knjiga i preneseni u ilustracijski repertoar tiskanih izdanja tih istih knjiga. ${ }^{21}$

Sačuvane narativne ilustracije, koliko god djelovale skromno, ipak zaslužuju kratki osvrt. Pritom valja reći da je ilustracija uz službu Duha Svetoga rađena prema standardnoj ikonografskoj shemi Silazak Duha Svetoga, dok ilustracije uz službu za pokojne i Svetoga Križa iznose specifična ikonografska rješenja. Ispred početka teksta uz službu mrtvih prikazana je scena blagoslova tijela kao sastavnog dijela obreda nad pokojnikom. ${ }^{22}$

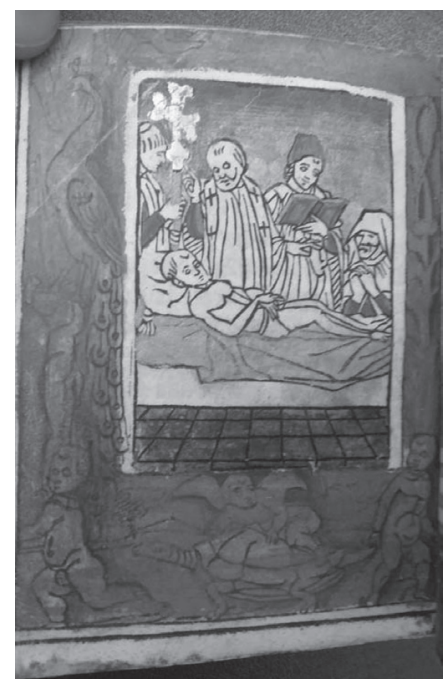

S1. 4. Blagoslov tijela pokojnika, Oficij BDM, Dobrić Dobrićević (Boninus de Boninis), Verona, 1481. Bassano del Grappa, Museo, Biblioteca Archivio.

Fig. 4. Blessing of the body of the deceased, Office of the BVM, Dobrić Dobrićević (Boninus de Boninis), Verona, 1481. Bassano del Grappa, Museo, Biblioteca Archivio.

On leži razodjeven na postelji iza koje stoji svećenik s dva asistenta. Jedan drži pozlaćeni križ, drugi otvorenu obrednu knjigu. Do njih sklopljenih ruku kleči žena u molitvi, vjerojatno pokojnikova žena. Prostor u kojem se radnja događa tek je naznačen mrežom podnih pločica i krevetom. Svođenje radnje na glavne likove s vizualno naglašenim tijelom pokojnika sugestivno priziva bespomoćnost čovjeka pred neumitnošću umiranja. Glavni prikaz uokviren

${ }^{21}$ Naći ćemo ih i na stranicama tzv. Dubrovačkog molitvenika, tiskanog 1512. u Veneciji, dakle punih trideset godina nakon Dobrićevićeva oficija.

22 Iako Dondi (2016: 67) navodi da je prikazan obred posljednje pomasti, čini se ipak da je riječ o blagoslovu mrtvoga tijela (usp. WIECK 1988: 128, 129). 
je ovlaš koloriranim drvorezom na kojem su dolje prikazani spiritelli u igri s kornjačom, životinjskim likom bogate semantike, koji ovdje - u skladu s prizorom umiranja - ima značenje i simboliku uskrsnuća. ${ }^{23} \mathrm{Na}$ lijevoj strani, duž čitavoga ruba slike, u profilu je prikazan raskošan paun, rajska ptica i simbol čežnje za nebom. ${ }^{24}$

Kasnija talijanska ilustrirana izdanja oficija iz 15. stoljeća donose različite inačice sličnoga obreda nad pokojnikom, pri čemu je najčešće riječ o blagoslovu pokojnika na odru. Na mnogima su detalji radnje u narativnom pogledu znatno bogatiji. ${ }^{25} \mathrm{~S}$ druge strane, u Platašićevu oficiju, pa i u mnogim rukopisnim časoslovima skromnije likovne opreme, u inicijalima uz početak službe za pokojne prikazana je mrtvačka lubanja kao jednostavan simbolički podsjetnik na smrt. ${ }^{26}$ Tema blagoslova pokojnika, koja podsjeća na obred bolesničkog pomazanja, u duhu ars moriendi predočava promatraču važnost »dobroga umrića«, tj. dobre smrti. Taj je motiv izvanredno široko zastupljnen u srednjovjekovnoj teologiji pobožnosti, sa snažnim poticajima koji su dolazili od novih tehnika mehaničkog umnožavanja slika, drvoreza i bakroreza. ${ }^{27}$

U ovom kontekstu zgodno je podsjetiti na to da je u Dubrovačkom molitveniku iz 1512. na tom mjestu otisnut novozavjetni prizor Uskrisenja Lazara. U Dešićevu Raju duše iz 1561. na početku službe za pokojne nalazi se ilustracija s prikazom imago pietatis, na kojem Bogorodica i jedan anđeo pridržavaju mrtvo Kristovo tijelo. U značenjskom je središtu svih tih ilustracija upravo tijelo - jednom običnog čovjeka-smrtnika, drugi put biblijskog Lazara, treći put samoga Isusa. Svaka je ilustracija na svoj način poticajna za meditaciju o neumitnosti tjelesne smrti koju je iskusio i sam Krist. Upravo ovaj primjer pokazuje da ilustracije nisu samo sporedan likovni dodatak ili puki ukras knjizi, već su one itekako važan vizualni sadržaj časoslova kojemu je zadaća da snažno utječe na molitveno raspoloženje korisnika.

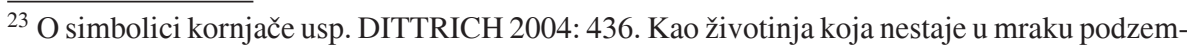
lja i ponovo se iz njega vraća na svjetlo dana, kornjača je čest simbol uskrsnuća. S tim značenjem prikazuje ju, primjerice, Dobrićevićev suvremenik, oponašatelj Andree Mantegne, na slici Svete žene na grobu (DITTRICH 2004: 438).

${ }^{24}$ O simbolici pauna usp. DITTRICH 2004: 347.

${ }^{25}$ Opaske o tome i primjere vidi u DONDI 2016: 67, sl. 32., 48., 54., 56., 58., 61.

${ }^{26} \mathrm{U}$ ovom sklopu pomišljamo na simboliku smrti u poznatim hrvatskim rukopisnim oficijima. Primjerice, u tzv. Akademijinom dubrovačkom molitveniku, danas u Arhivu HAZU, sign. VII. 17, osim mrtvačke lubanje na početku službe za pokojne u tom je dijelu časoslova naslikan još jedan inicijal u kojem je prikazan kostur smrti (usp. CVETNIĆ 2008). Za opširan opis ikonografije minijatura u Akademijinom dubrovačkim molitveniku i u Vatikanskom hrvatskom molitveniku v. PRIJATELJ-PAVIČIĆ 2011: 220.

${ }^{27}$ Usp. HAMM 2010: 470. 


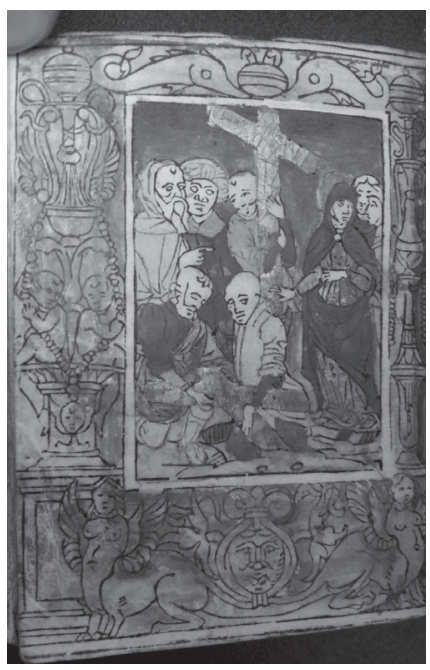

S1. 5. Nalazak sv. Križa, Oficij BDM, Dobrić Dobrićević (Boninus de Boninis), Verona, 1481. Bassano del Grappa, Museo, Biblioteca Archivio.

Fig. 5. Finding of the Holy Cross, Office of the BVM, Dobrić Dobrićević

(Boninus de Boninis), Verona, 1481. Bassano del Grappa, Museo, Biblioteca Archivio.

Zanimljivo ikonografsko rješenje nudi također ilustracija na početku službe Svetoga Križa. U skromnije oslikanim rukopisnim i tiskanim časoslovima ta služba obično započinje inicijalom u kojem je prikazan križ, kao što je slučaj u gore spomenutom Paltašićevom časoslovu i u tzv. Akademijinom dubrovačkom molitveniku. ${ }^{28}$ Zahtjevnije oslikani molitvenici donose prikaz Isusova raspeća, često u proširenoj naraciji s drugim protagonistima radnje na Golgoti. Katkad se u inicijalima na početku službe pojavljuje Isusovo izmučeno poprsje (lat. imago pietatis, Christo passo) s križem u pozadini. ${ }^{29}$ Dobrićević je početak te službe u svom oficiju ilustrirao temom nalaska svetoga križa. Na slici je desno kao obična žena s aureolom prikazana sv. Helena, majka cara Konstantina, koja rukom pokazuje prema skupini muškaraca koji su već iskopali dva križa, oba pozlaćena. Reducirana naracija prizora nije omogućila prikaz trećega križa, no on se za promatrača podrazumijeva. Uključivanje sv. Helene simbolički pojačava ulogu vjernika u štovanju Isusova križa i svega onoga što on znači za kršćanstvo. Slika je ujedno i podsjetnik

${ }^{28} \mathrm{U}$ Akademijinu dubrovačkom molitveniku naslikan je križ s natpisom »INRI« na azurnoj pozadini. Na njega su kao simboli Isusove muke i smrti na križu naslonjeni koplje s jedne i trska sa spužvom s druge strane. (CVETNIĆ 2008: 73).

${ }^{29}$ Vidi primjere u: DONDI 2016: 272, 292, 349, sl. 11, 16, 44. 
na događaj kojim je na čudesan način potvrđena sveta povijest otkupljenja. U tiskanim talijanskim oficijima kasnoga 15 . stoljeća ta se tema pojavljuje samo u još jednom oficiju što ga je Johannes Hamann 1494. tiskao u Veneciji za engleskog naručitelja. ${ }^{30}$ Birajući ilustracije za početak ovoga poglavlja u svojim izdanjima časoslova, Franjo Ratković i Nikola Dešić opredijelili su se za »standardni« prikaz motiva raspeća na Golgoti. Isto vrijedi i za oficije koje je Dobrićević dao tiskati u Lyonu.

\subsection{Dobrićevićevi časoslovi tiskani u Lyonu}

Sadržajem i grafičkim dizajnom Dobrićevićevi časoslovi objavljeni u Lyonu znatno se razlikuju od veronskoga izdanja. Oni pripadaju dugoj, izvanredno plodnoj francuskoj tradiciji izrade molitvenih knjižica. Na ilustracije Dobrićevićevih lyonskih časoslova osvrnuo sam se vrlo sažeto prije gotovo dvadeset godina (PELC 2000: 147). Ovom prilikom želio bih dopuniti i proširiti tadašnja zapažanja i pojasniti bibliografske nejasnoće, osobito kad je riječ o primjerku časoslova koji se čuva u Zagrebu. ${ }^{31}$ Pobliže bavljenje primjercima u Veneciji otvorilo je $\mathrm{k}$ tome zanimljive uvide u način korištenja i kasniju sudbinu tih popularnih molitvenika. Naime, u Lyonu, gradu koji je postao postaje najveće tiskarsko središte Francuske poslije Pariza, Dobrićević je objavio tri bogato ilustrirana izdanja časoslova Blažene Djevice Marije: dva 1499. i jedno 1501. Njemu je time pripala zasluga tiskanja prvog časoslova u Lyonu. ${ }^{32}$ Zapravo, kolofoni nijednog od spomenutih triju oficija ne sadrže ime(na) tiskara, što je pomalo neobično

30 Tiskan je pod naslovom Horae ad usum Sarum (Salisbury). Tema ilustracije je Sveta Helena klanja se Svetom križu (DONDI 2016: 385). Jedan francuski primjer iz rukopisnog oficija ranog 15. stoljeća donosi Roger Wieck (1988: 90). Prikazana je sv. Helena u trenutku dok dvojica radnika iskopavaju križ. Wieck (1988: 223) opisuje još jedan rukopisni oficij, tzv. Časoslov Adimarijevih (nastao u Firenci sredinom 15. stoljeća), u kojem je u inicijalu na početku službe sv. Križa prikaz Helene s pravim križem, a na donjoj margini prizor u kojem Helena provjerava križ: https://art.thewalters.org/detail/3851/initial-p-with-saint-helen-andthe-true-cross-2/ (7. 11. 2019.)

${ }^{31}$ Osim toga valja korigirati i pogrešno navedenu tehniku ilustracija koje nisu drvorezi već metalorezi.

${ }^{32} \mathrm{Za}$ bibliografske opise časoslova v. ISTC: https://data.cerl.org/istc/_search?query=+de+bon inis+horae \&from $=0$ (7. 11. 2019.) Prema kolofonima prvo izdanje bilo je 20.3.1499., drugo 20. 5.1499. a treće 26. 8. 1501. ISTC bilježi i izdanje iz 1500., no ono je, kako ćemo vidjeti, samo inačica izdanja iz 1501. Starija francuska literatura navodi kao prvo izdanje ono od 20. 5. 1499., dok se ono od 20. 3. bilježi kao drugo izdanje s godinom 1500. Usp. CLAUDIN 2014: 287; LACOMBE 1907: br. 500. 
za izdanja toga doba, ali se u njima navodi »expensis Bonini de Boninis « što znači da su ta izdanja tiskana o trošku Dobrićevića, tj. da im je Dobrićević bio nakladnik. ${ }^{33}$

U bibliografskoj literaturi provlači se podatak da su časoslove za Dobrićevića tiskala dvojica tiskara koji su u Lyon došli iz Italije: Jacobinus Suigus (podrijetlom iz mjesta San Germano kod Milana) i Nicolaus de Benedictis (podrijetlom iz Katalonije), iako se u kolofonima Dobrićevićevih časoslova njihova imena ne navode. ${ }^{34}$ Obojica su 1480-tih godina samostalno tiskali knjige u Veneciji (NEEDHAM 1998: 174, 178). Kao partneri su djelovali od 1489. godine, najprije u Torinu, a potom u Lyonu od $1496 .{ }^{35}$ Međutim, Suigo svoju tiskarsku djelatnost prekida već 1499., dok de Benedictis nastavlja raditi u Lyonu do 1513., a onda još u Torinu do 1519. Valja spomenuti da Dobrićević jest surađivao sa Suigom, ali na posve drugačijem području. Naime, kao informator (doušnik) mletačkog Vijeća desetorice, zadužen za izvješćivanje o političkim i vojnim zbivanjima na jugu Francuske, Dobrićević je kontakte s Vijećem održavao upravo preko knjižara, tiskara i knjigoveže Jacopa Suiga, tada tiskara u Torinu, koji je pak Dobrićevićeve poruke prosljeđivao Marcu Zorziju, mletačkom ambasadoru u Savoji, a ovaj ih je slao u Veneciju (DELLA SANTA 1915: 179; CIONI 1970: 216).

Suigo i de Benedictis su 31. siječnja 1495. u Torinu objavili vlastito tiskano izdanje oficija Blažene Djevice Marije »prema rimskom običaju « (DONDI 2016: 388), ali ono nema nikakve veze s Dobrićevićevim lyonskim izdanjima. ${ }^{36}$ Stariji bibliografi bilježe Suiga i de Benedictisa kao tiskare Dobrićevićeva oficija vjerojatno zbog toga što se slova upotrijebljena za tiskanje Dobrićevićeva časoslova od 20. svibnja 1499. podudaraju s onima koja su

${ }^{33}$ Treba spomenuti da su ilustracije Dobrićevićeva oficija upotrebljene i u izdanjima časoslova Luc'Antonia Giunte u Lyonu 1504. i 1505. Usp. VALENTINELLI 1870: 79.

${ }^{34}$ Usp. ISTC: https://data.cerl.org/istc/_search?query=+de+boninis+horae\&from=0 (7. 11 . 2019.). U toj danas najmjerodavnijoj bazi podataka o inkunabulama kao tiskari lionskih izdanja Dobrićevićeva časoslova u uglatim se zagradama navode Jacobinus Suigus i Nicolaus de Benedictis. O Suigu i de Benedictisu v. CIONI 1966: 454-455; AMELUNG 1987: 291-292; DE PASQUALE 2002: 79-104.

${ }^{35}$ O djelatnosti Suiga i de Benedictisa u Lyonu iscrpno piše Claudin (1914: 261-278), nigdje ne navodeći da bi nešto tiskali za Dobrićevića.

${ }^{36}$ Jedini poznati primjerak tog oficija čuva se u Herzog August Bibliothek u Wolfenbüttelu, sa signaturom A:918.8Theol (SANDER 1942 - 1943: br. 5057). Dondi istim tiskarima pripisuje još jedno izdanje oficija s nesigurnom godinom, tj. datira ga oko 1500., premda su tiskari u to vrijeme već u Lyonu (DONDI 2016: 447). Prema Dondi jedini poznati primjerak tog izdanja čuva se u Veneciji, Seminario Patriarcale, Inc. 81. Međutim, PETRELLA 2010: 69-70, nr. 37, tu knjigu opisuje kao Heures à l'usage d'Rome, Paris, Ph. Pigouchet per Simon Vostre, 15.10.1499. 
Suigo i de Benedictis upotrebljavali za svoja lionska izdanja pravnih knjiga. Iz toga se zaključivalo da je riječ o istom kompletu tiskarskih slova, tj. da su i Dobrićevićev oficij tiskali Suigo i de Benedictis. No, ne mora nužno biti tako, jer postoji mogućnost da je Dobrićević kao iskusan tiskar otkupio ili posudio njihove matrice i dao izliti novi komplet slova za svoje potrebe (CLAUDIN 1914: 291) ${ }^{37}$ U svakom slučaju, autoritet poput Claudina navodi da je Dobrićević sam tiskao časoslov, a u novijoj se bibliografijskoj literaturi Suigo i de Benedictis uopće ne spominju kao tiskari Dobrićevićeva oficija (GÜLTINGEN 1992: 103; 1993: 5). ${ }^{38}$

Premda se u Dobrićevićevim biografijama obično navodi da je u Lyonu prije svega djelovao kao nakladnik i knjižar, on je bez sumnje bio i tiskar. Naime, ubrzo nakon dolaska u Lyon u travnju 1498. u popis obveznika lyonske milicije (franc. les rôles de la milice lyonaise) upisan je kao tiskar (CLAUDIN 1914: 285). Osim toga, u kolofonu misala za biskupiju Chalon-sur-Saône (lat. Cabilonensis diocesis) od 17. prosinca 1500. Dobrićevićevo je ime navedeno u okviru formule uvriježene za tadašnje tiskare: lat. Impressum Luguduni per Boninum de Boninis de Raguxia, natione Dalmata. ${ }^{39}$ Dobrićević je, dakle, u Lyonu djelovao kao tiskar, pa ostaje nejasno zbog čega se u kolofonu izdanja svojih časoslova naveo samo kao nakladnik.

Tri izdanja Dobrićevićeva oficija iz 1499. i 1501., sva tri tiskana na pergameni, na prvi pogled djeluju vrlo slično, no podrobnijom usporedbom opaža se niz značajnih razlika. ${ }^{40}$ Primjerice, u izdanjima iz 1499 . kalendar je složen tako da su dani jednog mjeseca raspoređeni na verso stranici jednoga lista i recto stranici sljedećega lista tako da čitatelj, otvorivši knjigu na tom mjestu, odjednom vidi sve dane jednog mjeseca. Nasuprot tomu, u izdanju 1501. dani su jednog mjeseca raspoređeni na recto i verso stranici istog lista, što je za čitatelja manje spretno rješenje. Zatim, uže rubne slike s figurama u prva dva

${ }^{37}$ U Lyonu Dobrićević je dao tiskati i dva misala: Missale ad usum Cabilonensis diocesis (tj. biskupiju Chalon) 1500. i Missale ad usum insignis ecclesiae Bellicensis (biskupija Belley) 1503.

${ }^{38}$ LACOMBE 1907: br. 500, u opisu Dobrićevićeva oficija također ne spominje mogućnost da bi ga tiskali Suigo i de Benedictis.

${ }^{39}$ Za bibliografski zapis v. ISTC: https://data.cerl.org/istc/im00653100. (16. 4. 2019.).

${ }^{40}$ Konzultirani primjerak izdanja od 20. 3. 1499. čuva se u Biblioteca del Museo Correr u Veneciji (sign. INC. I 55.). Primjerak izdanja od 20. 5. 1499. čuva se u Bayerische Staatsbibliothek u Münchenu (sign. Ink H-343), a konzultiran je u elektronskom obliku (DOBRIĆEVIĆ 20.5.1499.). Konzultirani primjerci izdanja iz 1501. čuvaju se u Nacionalnoj knjižnici sv. Marka (tal. Biblioteca Nazionale Marciana) u Veneciji (sign. Membr. 72), opisan u: VALENTINELLI 1870: 79, i u Zagrebu, Nacionalna i sveučilišna knjižnica (sign. $R$ I-16 $6^{\circ}$-6). Zagrebački primjerak dostupan je u elektronskom obliku (DOBRIĆEVIĆ 1501.). 
izdanja otisnute su na vanjskom a u trećem na unutrašnjem dijelu margine. Između dvaju izdanja iz 1499. nema razlike u rasporedu većih ilustracija na početcima važnih dijelova molitvenika, no ima razlika u rasporedu sličica na rubovima stranica, dok se izdanje iz 1501. od dvaju izdanja iz 1499. razlikuje u oba netom navedena rasporeda slikovnog materijala. U svakom od tri izdanja nalazi se po 17 većih sličica, pri čemu je Navještenje Marijino u svakom otisnuto tri puta. Uz večernju otisnut je u izdanjima iz 1499. Pokolj nevine dječice, a u izdanju iz 1501. prikaz Marijina pohođenja Elizabeti koji je upotrijebljen i na početku lauda.

Pojedini primjerci istog izdanja često se odlikuju vlastitim značajkama, koje ih razlikuju od drugih primjeraka. O tome da svaka knjiga ima svoju sudbinu u kojoj se njezina povijesna uporaba stapa s intervencijama kolekcionara na izvrstan način svjedoči primjerak izdanja Dobrićevićeva oficija od 20. 3. 1499. koji se čuva u knjižnici Muzeja Correr u Veneciji, a prethodno ga je posjedovao glasoviti venecijanski erudit i kolekcionar Emmanuele Cicogna. Primjerak u Muzeju Correr tiskan je na pergameni, ali je povezan s papirnim tiskanim primjerkom istoga izdanja koji se čuva u Nacionalnoj knjižnici sv. Marka u Veneciji. ${ }^{41}$ Na početnoj stranici svog primjerka Dobrićevićeva oficija Cicogna je ostavio vlastoručnu bilješku u kojoj navodi da je tom primjerku tiskanom na pergameni nedostajalo nekoliko listova. Njih je Cicogna nadoknadio tako što je uzeo odgovarajuće listove iz nekog primjerka istoga oficija tiskanog na papiru (za koji ne znamo je li tada bio oštećen ili cjelovit) i umetnuo ih u svoj primjerak. Osim toga iz papirnog je oficija izrezao i listove koje su u pergamentnom primjerku sačuvani, ali su sličice na njima izlizane korištenjem. Tako je uz pojedine oštećene originalne pergamentne listove Cicognin primjerak dobio odgovarajuće papirne listove s jasno otisnutim tekstom i slikama. Nadalje, Cicogna je iz papirnog primjerka izrezao i na odgovarajuća mjesta u svoj pergamentni primjerak zalijepio niz rubnih, malih sličica, koje su u njegovom primjerku tiskanom na pergameni također bile izrezane. Pretežito su to bile sličice s likom Veronike s rupcem (tal. sudario).

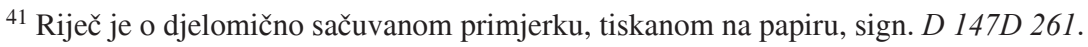




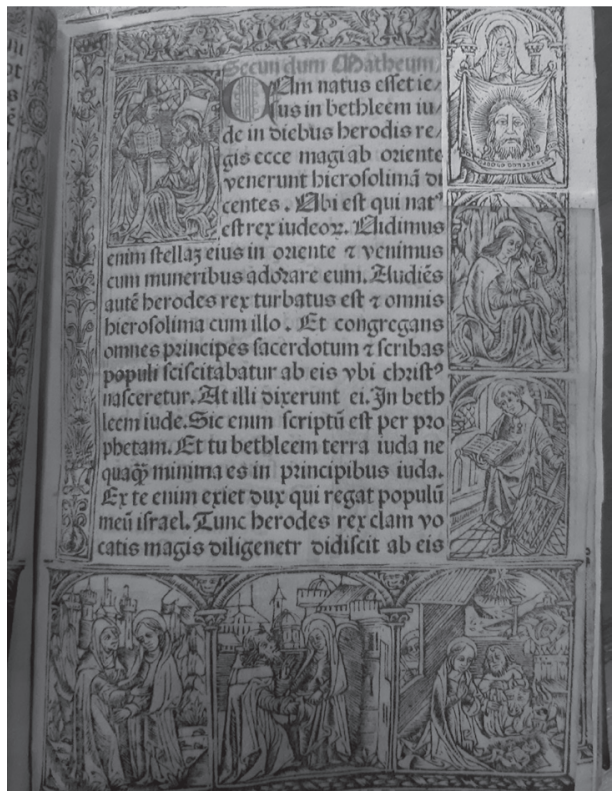

S1. 6. Stranica s ulijepljenom sličicom sv. Veronike, Oficij BDM, Dobrić Dobrićević (Boninus de Boninis), Lyon, 20. 3. 1499. Venecija, Biblioteca del Museo Correr.

Fig. 6. Page with an inserted image of Saint Veronica, Office of the BVM, Dobrić Dobricević (Boninus de Boninis), Lyon, 20 March 1499. Venice, Biblioteca del Museo Correr.

Na njima je zapravo glavni motiv Kristovo lice (lat. vera icon 'prava/vjerna slika' ili tal. volto santo 'sveto lice'), vrlo omiljen u srednjovjekovnoj pobožnosti. ${ }^{42}$ Tako je Cicogna doslovnim postupkom izrezivanja i lijepljenja iz dva primjerka dobio jedan, više nego kompletan primjerak časoslova. Sličice s Veronikom i rupcem iz pergamentnog su primjerka vjerojatno izrezane da bi se koristile kao apotropeji, amuleti ili amajlije za zaštitu od uroka i drugog zla. Pregledom djelomično sačuvanog primjerka tiskanog na papiru koji se čuva u Biblioteci sv. Marka ustanovio sam da su s nekih listova izrezane sličice s motivom Veronike i rupca, a usporedbom s primjerkom koji se čuva u Knjižnici Muzeja Correr lako sam mogao zaključiti da su upravo sličice iz tog papirnog primjerka ulijepljene u pergamentni primjerak koji je nekoć pripadao Cicogni. Nema sumnje da je fragmentarno sačuvani papirni primjerak iz Nacionalne knjižnice sv. Marka poslužio Cicogni pri opremanju pergamentnog primjerka o kojem će još biti riječi.

$\overline{42}$ Usp. BÜTTNER, GOTTDANG 2006: 74. Za štovanje Veronikina rupca i primjere prikaza volto santo u glagoljskim misalima usp. MOKROVIĆ 2013. 


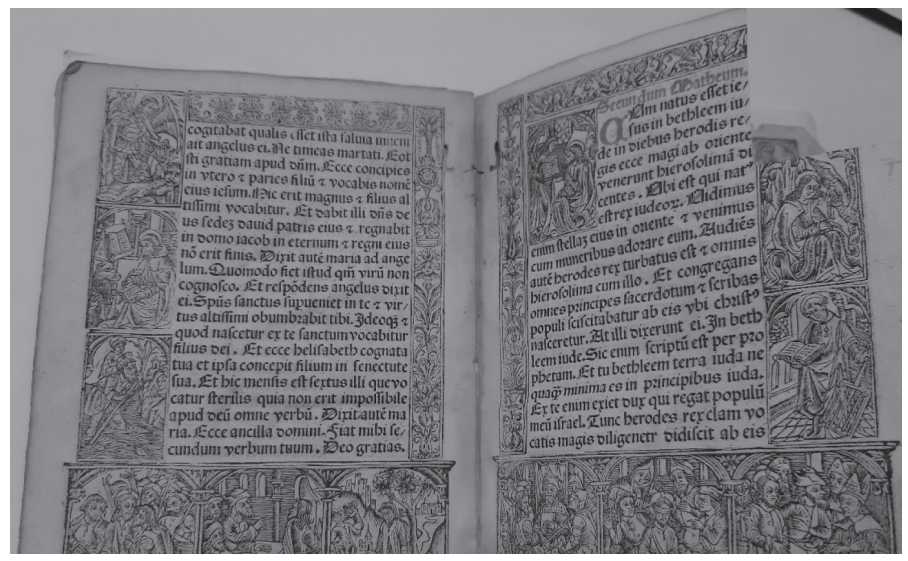

S1. 7. Stranica s izrezanom sličicom sv. Veronike, Oficij BDM, Dobrić Dobrićević (Boninus de Boninis), Lyon, 20. 3. 1499. Venecija, Biblioteca Nazionale Marciana.

Fig. 7. Page with a cut-out image of Saint Veronica, Office of the BVM, Dobrić Dobricević

(Boninus de Boninis), Lyon, 20 March 1499. Venice, Biblioteca Nazionale Marciana.

I primjerak Boninusova oficija koji posjeduje Nacionalna i sveučilišna knjižnica u Zagrebu, kupljen na dražbi 1997., ima svojih posebnosti. On je po svemu, uključujući i datum tiska (26. kolovoza) identičan primjercima iz 1501. godine, osim što u kolofonu stoji godina 1500., što su neki bibliografi protumačili kao još jedno izdanje časoslova. ${ }^{43}$ Međutim, ovdje je bez sumnje riječ o tehničkoj grešci koja se potkrala prilikom tiska. Naime, pri tiskanju (rimska) brojka »I« nije primila crvenu boju ili se zbog nekog razloga pri otiskivanju boja nije prenijela na pergamenu, pa je umjesto godine »MCCCCCI vidljivo samo »MDCCCCC « ${ }^{44}$ Taj primjerak, pripada, dakle, izdanju iz 1501. godine, a izdanje iz 1500. nije potvrđeno, tj. vjerojatno ne postoji.

U svim izdanjima upotrijebljena je ista ilustracijska oprema, no raspored slika nije identičan. Sva su izdanja reprezentativni primjeri tzv. francuskog stila u likovnom opremanju tiskanih oficija. $U$ tu svrhu razvijena je razmjerno rijetka tehnika pripreme ilustracija na metalnom pločama (metaloreza) u postupku visokog tiska, koji je po efektu gotovo do neprepoznatljivosti sličan

${ }^{43}$ Zagrebački primjerak u Nacionalnoj i sveučilišnoj knjižnici iscrpno je opisan u: KOSIĆ 1998: 62-78. Tu je navedena i starija bibliografija.

${ }^{44}$ Usp. Gesamtkatalog der Wiegendrucke, gdje je opisan upravo zagrebački primjerak: »U pergamentnom primjerku koji je prošao kroz zbirke Colbert, Essling i Yves Guermont, da bi bio prodan na dražbi kod Raucha (Genève) N.S. 3. 2. - 4. III. 1953 Nr 34, pa potom kod Sotheby'sa (London) 15.V.1997 Nr 58, 'i' u impresumu nije primilo boju, pa se nije ni otisnulo. Tisak se u potpunosti poklapa s izdanjem od 26.VIII.1501.« https://gesamtkatalogderwiegendrucke.de/docs/GWXI429A.htm (8. 11. 2019.) 
drvorezu, s time da su metalne ploče (najčešće od bakra) mogle podnijeti veću nakladu od drvenih. To je vjerojatno i glavni razlog što su metaloreze posebno često koristili francuski tiskari i izdavači koji su objavili brojna izdanja časoslova s istim kompletima ilustracija i stvorili specifičan standard njihova ilustriranja, nazvan »francuskim stilom $\ll .{ }^{45}$ Taj »francuski « način ilustriranja oficija formiran je već osamdesetih godina 15. stoljeća u Parizu. ${ }^{46}$ Sve stranice ondje tiskanih časoslova ispočetka su bile uokvirivane sličicama izduženog, okomitog ili vodoravnog formata, koji se po volji mogu kombinirati i ponavljati. Najčešća su dva tipa takvih ilustracija: uske i okomite s dekorativnim uzorcima i figurama, te šroke i vodoravne s prizorima iz Starog i Novog zavjeta, likovima proroka, evanđelista i svetaca, motivima plesa smrti, likovima sibila i sl. Uz kalendar otisnuti su tipični prikazi radova i aktivnosti primjerenih pojedinom mjesecu odnosno njegovom astrološkom znaku. Treba pritom zamijetiti da korespondencija između glavnog teksta na stranici i sličica smještenih ispod i oko njega uglavnom nije bila obvezujuća. Iste sličice, posebice figure svetaca, višekratno se i bez pravila, ponavljaju na različitim mjestima u različitim poglavljima oficija. Kad je riječ o malim tematskim ciklusima, priređivači su pazili na to da njihov sadržaj odgovara sadržaju dotičnog poglavlja. Tako, primjerice, službu za pokojne ilustrira ciklus plesa smrti, dok se uz časove službe Blažene Djevice Marije nižu sličice iz ciklusa Marijina i Isusova života, kojima su dodane sličice sa sibilama - navjestiteljicama pojedinih važnih događaja otkupiteljske povijesti.

Početke pojedinih službi oficija i određenih časova u njima naglašavali su veći prikazi, također uokvireni, s odgovarajućim ikonografskim sadržajem. U francuskim časoslovima takvih je većih prikaza obično između četrnaest i sedamnaest. Naposljetku, osim sićušnih slika na marginama stranica mnogih časoslova u posebnim su okvirićima otisnuti kratki izvaci iz evanđelja odnosno djela crkvenih naučitelja, kojima se, kao svojevrsnim hipertekstovima, proširuje meditacijski potencijal molitvenika. Tako bogatom i složenom likovnom opremom francuski su se časoslovi nastojali što više približiti rukopisnim,

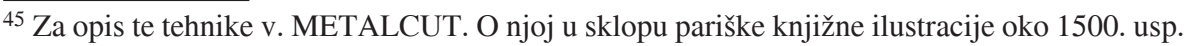
NETTEKOVEN 2004: 70. CLAUDIN 1914: 286, navodi da su neke ilustracije izrađene kao drvorezi a neke kao metalorezi, no to je praktički nemoguće raspoznati. Tehniku metaloreza prihvatili su i venecijanski tiskari, u prvom redu Petrus Lichtenstein, koji je tiskao mnoga liturgijska djela, posebice misale i brevijare, početkom 16. st. Usp. GOFF, 242.

${ }^{46}$ Usp. CLAERR 2000, sv. 1, 5; sv. 2, 14. Pariški tiskari Antoine Vérard, Jean du Prè, Philippe Pigouchet, Simon Vostre i drugi razvili su koncem 15. stoljeća masovnu proizvodnju časoslova. Slijedio ih je Thielman Kerver, Nijemac iz Koblenza (djeluje u Parizu od 1497. do 1522.), »specijalist za časoslove«, koji je već u prvoj godini svoje aktivnosti objavio sedam izdanja. Usp. HARTHAN 1977: 169. 
iluminiranim uzorima, što im je i uspjelo kao rijetko gdje u povijesti ranoga tiskarstva (KRISTELLER 1921: 111).

Ilustracije oficija bile su korisnicima svakodnevan vizualni podsjetnik na glavne sadržaje otkupiteljske povijesti u »džepnom« formatu. Dapače, zahvaljujući slikama, časoslove su mogli koristiti i analfabeti. Tiskari i izdavači oficija računali su s djelovanjem slika i na takvu publiku koja nije samostalno čitala tekst, već je gledajući slike mogla razumjeti sadržaj molitve i sudjelovati u njoj. Slike su u tim slučaju doista preuzimale ulogu teksta i služile kao svojevrsno »štivo nepismenih «. Izravno svjedočanstvo o tome pruža opširan kolofon oficija što ga je u Parizu 1533. izdala Yolande Bonhomme, udovica jednog od najplodnijih pariških tiskara časoslova, Thilmanna Kervera. U kolofonu tog časosova između ostalog stoji: Hore beatissime virginis Marie secundum usum Romanum novis imaginum figuris nuper adornate, nec ab re quidem, quam enim doctis inelligentiam prebent littere, hanc, procul dubio, rudibus ac idiotis prestant imagines secundum protritam hanc sententiam: "Pictura est laicorum scriptura."Per illam namque res signatas legunt et capiunt qui literas non norunt. ${ }^{47}$ (LACOMBE 1907: 83 i br. 397) Izdavač časoslova vodi, dakle, računa o tome da su nepismenima slike ono što su tekstovi onima koji znaju čitati, te da oni koji ne umiju čitati tekst zahvaljujući slikama mogu pratiti sadržaj časoslova i moliti iz njega.

Međutim, slike nisu samo pomagala za razumijevanje tekstova, odnosno njihova vizualna zamjena. One istodobno zastupaju svete osobe koje prikazuju. Dapače, one se doživljavaju kao njihovo utjelovljenje i kao posrednici njihove moći, što u najvećoj mjeri vrijedi za čudotvorne slike. ${ }^{48}$ Mentalno poistovjećivanje svetih osoba s njihovim prikazima potiče vjernike na pobožnu interaktivnost sa slikama: oni im se klanjaju, dodiruju ih i ljube - čime ih, dakako, i oštećuju. ${ }^{49}$ Upravo o takvom odnosu prema slikama u molitvenoj knjizi (koji ni danas nije rijetkost) svjedoči spomenuti primjerak Dobrićevićeva časoslova iz knjižnice Muzeja Correr, sa stranicama na kojima su mnoge slike pa i dijelovi teksta doslovce »izlizani« dodirivanjem prstima ili usnama. Najjače su izlizane stranice s najomiljenijim molitvama Bogorodici Obsecro te i $O$ intemerata, na kojima je lik Marije s djetetom Isusom u krilu, potom stranica s prikazom Raspeća na Golgoti, i - što je vrlo razumljivo - stranica

47 »Časoslov Blažene Djevice Marije prema rimskom običaju urešen je novim ilustracijama, kako bi se ono što učenima pružaju slova, neukima i priprostima omogućilo slikama, prema davnoj izreci: 'Slike su štivo nepismenih.' Naime, s pomoću njih označene sadržaje čitaju i razumiju oni koji slova ne poznaju.« (prijevod M. P.).

${ }^{48}$ Usp. o tome FREEDBERG 1989:28.

${ }^{49} \mathrm{O}$ (kreativnom) interaktivnom odnosu korisnika i slike na primjeru ranih drvoreza usp. AREFORD 2003: 9. 
sa slikom sv. Apolonije, zaštitnice od zubobolje. Te su stranice bile najčešće otvarane, a o drugim oblicima interaktivnosti, poput ljubljenja i pobožnog dodirivanja, može se zaključivati s velikom vjerojatnošću.

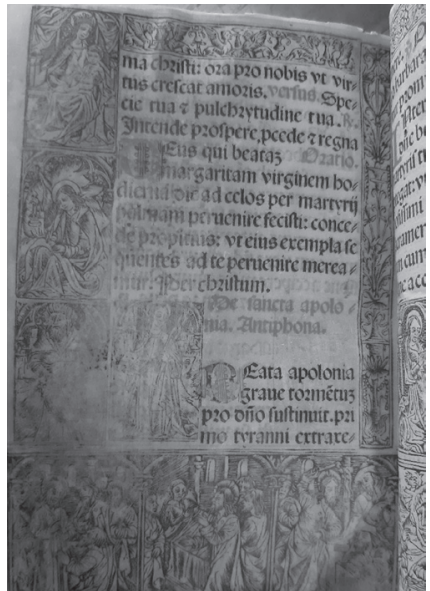

S1. 8. Izlizana stranica s molitvom sv. Apoloniji, Oficij BDM, Dobrić Dobrićević (Boninus de Boninis), Lyon, 20. 3. 1499. Venecija, Biblioteca del Museo Correr.

Fig. 8. Worn-out page with the prayer to Saint Apollonia, Office of the BVM, Dobrić Dobrićević (Boninus de Boninis), Lyon, 20 March 1499. Venice, Biblioteca del Museo Correr.

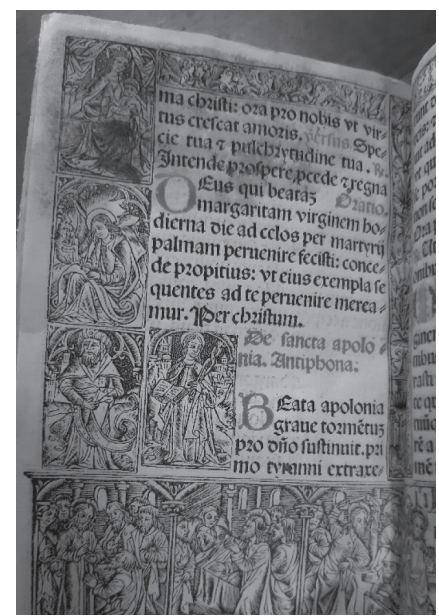

S1. 9. Neoštećena stranica s molitvom sv. Apoloniji, Oficij BDM, Dobrić Dobrićević (Boninus de Boninis), Lyon, 20. 3. 1499. Venecija, Biblioteca Nazionale Marciana.

Fig. 9. Undamaged page with the prayer to Saint Apollonia, Office of the BVM, Dobrić Dobrićević (Boninus de Boninis), Lyon, 20 March 1499. Venice, Biblioteca Nazionale Marciana. 
Međutim, dok su na tim stranicama oficija sličice izlizane dodirivanjem i ljubljenjem, na nekim stranicama jedan je lik namjerno i sustavno ostrugan i izbrisan. To je lik Sotone koji napastuje Isusa. Ilustracija s tim svetopisamskim prizorom ponavlja se u oficiju na više stranica, i svaki put lik Sotone temeljito je ostrugan. Pobožni je korisnik na taj način dao oduška svome gnjevu nad ocem svega zla, jednako kao što su to činili revoltirani promatra-

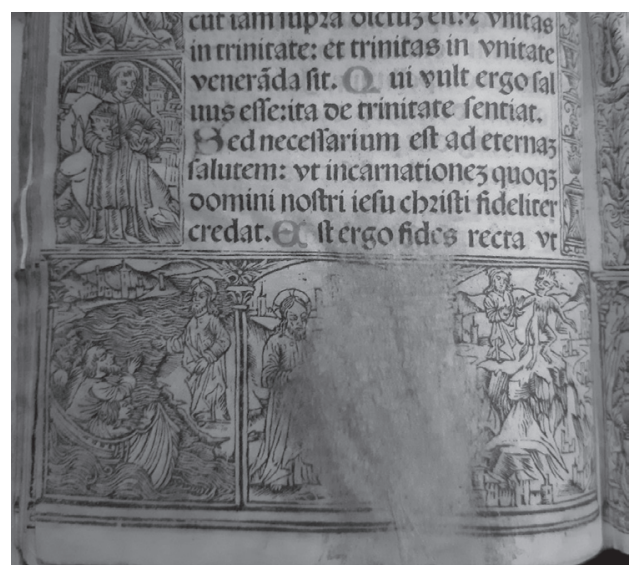

S1. 10. Stranica s ostruganim likom Sotone, Oficij BDM, Dobrić Dobrićević (Boninus de Boninis), Lyon, 20. 3. 1499. Venecija, Biblioteca del Museo Correr.

Fig. 10. Page with the erased figure of Satan, Office of the BVM, Dobrić Dobrićević (Boninus de Boninis), Lyon, 20 March 1499. Venice, Biblioteca del Museo Correr.

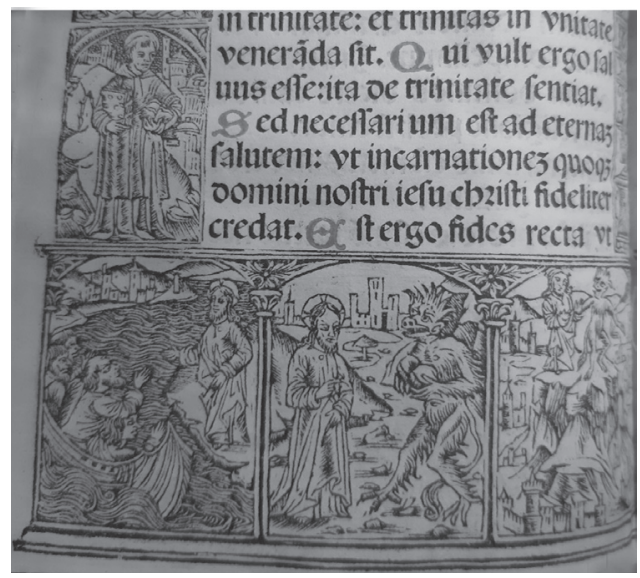

S1. 11. Stranica s neoštećenim likom Sotone, Oficij BDM, Dobrić Dobrićević (Boninus de Boninis), Lyon, 20. 3. 1499. Venecija, Biblioteca Nazionale Marciana.

Fig. 11. Page with the undamaged image of Satan, Office of the BVM, Dobrić Dobrićević (Boninus de Boninis), Lyon, 20 March 1499. Venice, Biblioteca Nazionale Marciana. 
či u crkvama, sakateći njegove prikaze na freskama ili dopisujući na njima pogrdne riječi. ${ }^{50}$

Detaljnija analiza ilustracija u Dobrićevićevu oficiju tražila bi mnogo prostora. Stoga ću se ovdje kratko zadržati samo na nekoliko ikonografskih osobina koje obilježavaju Dobrićevićev oficij, a pripadaju francuskoj tradiciji. Jedna od njih je prikaz kaleža s Kristovom ranom na boku i dva krilata gola anđelčića (erota ili spiritella) u njegovu podnožju. Taj motiv, povezan s pobožnostima muke i krvi Kristove, pojavljuje se u mnogim ranijim i kasnijim pariškim izdanjima oficija. ${ }^{51}$ Najbliži uzor Dobrićevićevoj slici nalazi se vjerojatno u časoslovu što ga je Philippe Pigouchet 22. 8. 1498. tiskao za Simona Vostrea, s tom razlikom da je slika u Pigouchetovom izdanju (PIGOUCHET 1498.) otisnuta ispred kalendara, a u Dobrićevićevom ona vizualno pripravlja na molitvu Kristovim ranama koja počinje na sljedećoj stranici.

Nadalje, na stranici pred početkom Bogorodičine službe otisnut je drvorez s prikazom Jišajevog stabla, kojim dominira Bogorodica s dječakom Isusom u naručju. Obično se ta tema prikazuje u misalima uz prvu nedjelju adventa, no ona je česta i u francuskim časoslovima. ${ }^{52} \mathrm{Na}$ stranici koja prethodi početku službe za pokojne otisnut je na lijevoj i donjoj margini drvorez s prikazom posljednjeg suda neprekinute L-kompozicije, tipične za sitnoslike u rukopisnim oficijima. Pritom je na lijevoj strani gore prikazan Krist sudac s anđelima i nebeskom pratnjom, dok se na donjoj margini otvara pakleno ždrijelo koje guta grešnike. Na ilustraciji uz početak službe za pokojne prikazan je dio sprovodnog rituala koji se odvija u crkvi - obred nad lijesom odnosno sarkofagom. Pogledu promatrača otvara se unutrašnjost crkve s velikim sarkofagom nad kojim svećenik u pratnji dvije skupine redovnika obavlja obred za pokojne. Istodobno, na donjoj margini započinje niz sličica s prikazima Mrtvačkog ple$s a$, također tipičan za francuske časoslove. Raspored pojedinih sličica razlikuje se u izdanjima Dobrićevićeva oficija iz 1499. i 1501., pri čemu priređivač nije previše mario za određeni redoslijed. Tako u izdanju od 20. svibnja 1499.

${ }^{50}$ Nekoliko primjera navodi Branko FUČIĆ (1963: 11). Riječ je o prikazima Heroda i đavla kojeg satire arkanđeo Mihovil na freskama Vincenta iz Kastva i radionice u Bermu (1474.). Na fresci Sotona napastuje Isusa u crkvi sv. Roka u Draguću, djelu Antona s Padove (1529.), Sotoni je također izgrebano lice, a postoje i drugi primjeri.

${ }^{51}$ Kalež, koji se katkad (bez opravdanja) naziva Sveti Gral, zapravo je svojevrstan spremnik u kojem se pokazuje Isusova rana u njezinoj pretpostavljenoj veličini (HARTHAN 1977: 169-170). O kasnosrednjovjekovnom štovanju takvih prikaza usp. AREFORD 2010.

${ }^{52}$ Vidi, primjerice, Jišajevo stablo u časoslovu koji je 1498. Pigouchet tiskao za Simonea Vostrea (PIGOUCHET 1498) ili u časoslovu što ga je 1502. i kasnije tiskao Thielman Kerver (CLAERR 2013: 413) i mnogi drugi (v. primjere u NETTEKOVEN 2004). 
niz započinje prikazima u kojima kostur odvodi eremita, sakristana i dijete, a u izdanju iz 1501. kostur odvodi kardinala, cara i papu.

Ciklus sibila, poganskih navjestiteljica novozavjetnoh događaja, također je uvriježen u francuskim časoslovima. Pigouchet u spomenutom oficiju iz 1498., koji je likovnom opremom vrlo blizak Dobrićevićevim izdanjima, na svakoj stranici pri dnu otiskuje sličicu s nekom od sibila, pri čemu se pojedine sličice mnogo puta ponavljaju. U Dobrićevićevu oficiju sibile su raspoređene na dnu stranice samo u poglavlju koje sadrži Bogorodičinu službu, no i tu se njihovi prikazi višekratno ponavljaju. Prikazane su najčešće kao žene s knjigama, njihovim glavnim atributima. Kod nekih sibila otvoreni i zatvoreni svesci leže u pejsažu, kod nekih su u interijeru sobe ili u otvorenom trijemu, na pultovima i oko njih, oblikujući prave male mrtve prirode s knjigama. Kao dodatak likovima proročica otisnuti su tekstovi njihovih proročanstava. Sve to, unatoč brojnim ponavljanjima pojedinih sličica, ukazuje na pažljivo ikonografsko i simboličko promišljanje ilustracija i želju da se njihovim promatranjem u povezanosti s tekstom čitaocu pruži što više duhovne koristi. Naposljetku, treba napomenuti da za razliku od većine onovremenih francuskih izdavača, Dobrićević na početku oficija ne uvrštava sliku tzv. zodijakalnog čovjeka, muškarca rastvorene utrobe s organima i udovima na kojima su označeni planeti koji na njih utječu. ${ }^{53}$

Ne znamo gdje je Dobrićević pribavio vrlo kvalitetne ilustracije za svoje lyonske časoslove. Njihov je vizualni karakter posve prožet obilježjima francuskog oblikovanja na razmeđi kasne gotike i renesanse, a njihov ikonografski fond mnogo je širi i tematski složeniji od onoga u talijanskim oficijima. Nema sumnje da su Dobrićevićevi metalorezi oponašali uzore iz Pariza, u prvom redu ilustracije iz brojnih izdanja oficija Jeana du Prèa, Simonea Vostrea, Thielmana Kervera, Philippea Pigoucheta i drugih, objavljenih u posljednjem desetljeću 15. stoljeća. ${ }^{54}$ No u njima se ipak osjeća i talijanski renesansni prizvuk, posebice u izostanku ili zatomljivanju kasnogotičkih motiva i ukrasa, odnosno u nastojanju oko skladne gradnje narativnih kompozicija prema pravilima geometrijske perspektive na ilustracijama većega formata. Kao potvrdu tome dovoljno je usporediti prikaz Silaska Duha Svetoga u Pigouchetovom

53 HARTHAN (1977: 170) donosi karakterističan primjer »zodijakalnog čovjeka« iz oficija koji je Pigouchet tiskao u Parizu 1500. - 1501.

${ }^{54}$ NETTEKOVEN 2004: 30, 87, pariške ilustracije tog vremena povezuje s raznolikim opusom anonimnog umjetnika kojeg naziva »Meister der Apokalypsenrose«, smatrajući ga autorom vitraja na velikom kružnom prozoru (ruži) Sainte-Chapelle u Parizu. Taj svestrani majstor, koji je radio u izrazito kasnogotičkom stilu, intenzivno se bavio izradom iluminacija rukopisa i predložaka za ilustracije u tiskanim knjigama, a ponekad se identificira kao Jean d'Ypres (NETTEKOVEN 2004: 4). 
izdanju iz 1498. (PIGOUCHET 1498.) s onim u Dobrićevićevim oficijima. Kod Pigoucheta ovalno izduljena skupina Bogorodice i apostola sjedi pod ušiljenim kasnogotičkim baldahinom u prostoriji koja se plošno diže prema gore. Kod Dobrićevića apostoli i Marija dočekuju golubicu Duha Svetoga pod elegantno zaobljenim renesansnim baldahinom u prostoru s nenametljivo usklađenim odnosima figura i prema dubini i prema visini. Budući da je Dobrićević u Lyon nastojao uvesti prizvodnju lijepih liturgijskih knjiga, koja je sjajno prosperirala u Parizu (CLAUDIN 1914: 291), on je za svoje časoslove pribavio ilustracije vrlo slične pariškima. U to se nastojanje uklapa i jedna tehnička odnosno likovna osobitost kojom se odlikuju Dobrićevićeve ilustracije. To je efekt tzv. punciranja, kojim se tamna pozadina sličica rezanih na metalnim pločama oživljava gustom mrežom svijetlih točkica, čime nastaje dinamičniji vizualni doživljaj. Tu je tehniku zvanu manière criblée uvelike rabio majstor koji je izrađivao ilustracije za Philippea Pigoucheta u Parizu oko 1498. Sažeteo rečeno, Dobrićevićeve se ilustracije u tehničkom i ikonografskom pogledu nadovezuju na ostvarenja pariških radionica, no u stilskom su pogledu one samosvojne, što se očituje u činjenici da je duh renesansnog oblikovanja u njima mnogo jači od privrženosti kasnogotičkim formulama, tipičnim za ilustracije oficija pariških tiskara i nakladnika oko 1500 . godine. ${ }^{55}$

\section{ZAKLJUČAK}

Tiskari hrvatskoga podrijetla Andrija Paltašić i Dobrić Dobrićević dali su značajan doprinos povijesti tiskanih oficija, tih srednjovjekovnih molitvenih »uspješnica«. Paltašić je bio drugi tiskar koji je u Veneciji tiskao mali oficij po uzoru na Nicolausa Jensona. Boninusov je obol znatno veći i značajniji. On je u svom veronskom izdanju 1481. prvi uveo drvorezne ilustracije u tiskani časoslov. Gotovo dva desetljeća kasnije opet je bio pionir: njegovo je izdanje od 20. 3. 1499. prvi lyonski oficij opremljen grafičkim ilustracijama. Četiri Boninusova izdanja oficija u sadržajnom, ikonografskom i likovnom pogledu vjerno i dosljedno odražavaju dva tradicionalna modela njihove izrade: talijanski i francuski. Dok veronsko izdanje u potpunosti odražava talijanski model,

55 Tu renesansnu, talijansku crtu Dobrićevićevih ilustracija prepoznao je i CLAUDIN 1914: 286: »Le dessin et l'execution de ces planches, où figure une Danse des Morts, sont d'un caractère italien qui les distingue de toute celles qui ont paru en France. « (Crtež i izvedba ilustracija, među kojima je i jedan ciklus Mrtvačkoga plesa, talijanskog je karaktera, i po njemu one se razlikuju od svih objavljenih u Francuskoj.) HIND 1963: 698, pak smatra da je Boninus ilustratora (autora predložaka) doveo iz Italije, no ploče su unatoč delikatnim linijama rezane nemarno. Po Hindu ilustracije odražavaju sjevernotalijanski stil kako u figurama tako i u krajoliku, a tehnika je drvorez (!). 
lyonska izdanja pripadaju francuskoj tradiciji, no oblikovanje ilustracija obilježeno je talijanskim renesansnim ukusom. Časoslovi francuske tradicije sadržajem su opširniji od talijanskih. Oni uključuju više novozavjetnih tekstova, a time i više ilustracija iz Isusova i Marijina života. U skladu s tim, francuska su izdanja u ikonografskom i dekorativnom smislu znatno bogatija od talijanskih. O ovom radu posebna je pažnja posvećena primjerku Dobrićevićeva oficija iz ožujka 1499., tiskanom na pergameni, koji se danas čuva u knjižnici Muzeja Correr u Veneciji. Budući da je bio oštećen, njegov prijašnji vlasnik, bibliofil Emanuele Cicogna, dopunio ga je listovima i izrezanim sličicama iz jednog primjerka istoga izdanja oficija tiskanog na papiru, koji se u fragmentima danas čuva u Nacionalnoj knjižnici sv. Marka u Veneciji. S jedne strane Cicognin oštećeni primjerak ukazuje na oblike praktične pobožnosti kojoj je oficij služio. S druge strane on je novi knjižni proizvod nastao u »radionici« kolekcionara Cicogne, koji je nastojao dobiti jedan kompletan primjerak i po cijenu sakaćenja drugog primjerka.

$\mathrm{Na}$ koncu spomenimo da su u Italiji tiskari i nakladnici nastojali preuzeti značajke francuskoga stila u ilustriranju oficija, no to preuzimanje bilo je samo djelomično i uglavnom izvanjsko. ${ }^{56}$ Za nas je osobito važno da jedan od izdanaka toga stila tzv. Dubrovački molitvenik Franje Ratkovića, tiskan 1512. u Veneciji kod Giorgia Rusconija. Stoga se i on s aspekta likovnosti može tumačiti u okvirima iste tradicije kojoj pripadaju Dobrićevićevi lyonski časoslovi. Naravno, postoje i mnoge razlike, no njihova bi analiza zahtijevala zasebnu studiju.

\section{IZVORI}

ČASOSLOV ADIMARIJEVIH. $=$ Adimari Book of Hours 1448. URL: https://art.thewalters.org/detail/3851/initial-p-with-saint-helen-and-the-true-cross-2/ (7. 11. 2019.)

JENSON = JENSON, N. [oko 1475.] Horae. Venedig: Nicolaus Jenson. URL: https:// daten.digitale-sammlungen.de/ db/0005/bsb00054071/images/index.html?seite $=4 \& \mathrm{f}$ $\mathrm{ip}=193.174 .98 .30(6.11 .2019$.)

DOBRIĆEVIĆ 20.5.1499. = Horae. Officium BMV secundum usum Romanum. Lyon: [Jacobinus Suigus und Nicolaus de Benedictis] za Boninus de Boninis. URL: http://

$\overline{56}$ Prvi tiskar koji u Italiji oponaša francuski model likovnog opremanja oficija bio je Andrea Torresani de Asula u Veneciji sa svojim časoslovom objavljenim 1489. On je unio različite zazive (suffragia) kao i molitvu Bogorodici Obsecro te, popularnu u francuskim izdanjima. Umjesto uobičajenih pet drvoreza uz pojedina poglavlja oficija on je upotrijebio 14 cjelostranih drvoreza s ilustriranim okvirima koji oponašaju francuski stil (DONDI 2016: 344). Taj način opremanja časoslova prihvatili su u Veneciji tiskari Johannes Hamman (1493.) i Nicolaus de Spira (1494.), potom i drugi. Usp. o tome DONDI 2016: 69. 
daten.digitale-sammlungen.de/ db/ausgaben/thumbnailseite.html?id=00074553\&sei te $=9 \&$ image $=b s b 00074553 \_00009 . j p g \&$ fip $=193.174 .98 .30$ (7. 11. 2019.)

DOBRIĆEVIĆ 1501. = Officium beate Marie virginis : ad usum Romane ecclesie. Lugduni : expe[n]sis Bonini de Boninis dalmatini. URL: https://digitalna.nsk.hr/pb/?o bject=v iew\&id=10599\&tify $=\{\% 22$ pages $\% 22:[1], \% 22$ view\%22:\%22scan\%22 $\}$ (7. 11. 2019.)

PIGOUCHET 1498. = [Horae ad usum Romanum. Lat. et fr. :] Heures à l'usaige de Romme. - Paris : Philippe Pigouchet pour Simon Vostre, 22. VIII. 1498. - $8^{\circ}$. Bibliothèque Sainte-Geneviève: OEXV 281 RES. URL: https://archive.org/details/OEXV281 (9. 11. 2019.)

\section{LITERATURA}

AMELUNG, P. 1987. Benedictis (Benedict), Nicolaus, de. Lexikon des gesamten Buchwesens. Stuttgart: Anton Hiersmann, 291-292.

AREFORD, D. S. 2003. The Image in the Viewers Hands. The Reception of the Early Prints in Europe. Studies in Iconography 24: 5-42.

AREFORD, D. S. 2010. The Viewer and the Printed Image in the Late Medieval Europe. Ashgate: Routledge.

BOŠNJAK, M. 1970. Slavenska inkunabulistika. Zagreb: vlastita naklada

BÜTTNER, F., GOTTDANG, A. 2006. Einführung in die Ikonographie. Wege zur Deutung von Bildinhalten. München: C.H. Beck.

CASTIGLIONI, G. 1986. Un secolo di miniatura veronese 1450 - 1550. Castiglioni, G., Marinelli, S. (ur.) Miniatura Veronese del Rinascimento. Verona: Museo di Castelvecchio, 45-101.

CIONI, A. 1966. Benedictis (de Benedictis), Nicolaus. Dizionario biografico degli Italiani. Rim: Istituto della Enciclopedia italiana, sv. 8, 454-455.

CIONI, A. 1970. Bonini (Boninis), Bonino. Dizionario biografico degli Italiani. Rim: Istituto della Enciclopedia italiana, sv. 12, 215-219. (online: http://www.treccani.it/ enciclopedia/bonino-bonini_(Dizionario-Biografico)/ (16. 4. 2019.)

CLAERR, TH. 2000. Imprimerie et réussite sociale à Paris à la fin de Moyen Âge: Thielman Kerver imprimeur-libraire de 1497 à 1522. Vol. 2. Paris: Sorbonne.

CLAERR, TH. 2013. L'édition des heures du 21 avril 1505: une oeuvre charnière dans la production de Thielman Kerver. Hindman, S., Marrow, J. H. (izd.). Books of Hours Reconsidered. Turnhout: Brepols, Harvey Miller Publishers.

CLAUDIN, A. 1914. Histoire d'imprimerie en France au XVe et au XVI siècle. Vol. 4. Paris: Imprimerie nationale.

CVETNIĆ, S. 2008. Akademijin dubrovački molitvenik i ikonografija smrti oko 1400. P. Marković, J. Gudelj (ur.) Renesansa i renesanse u umjetnosti Hrvatske. Zbornik radova sa znanstvenih skupova »Dani Cvita Fiskovića« održanih 2003. i 2004. godine. Zagreb: Institut za povijest umjetnosti; Odsjek za povijest umjetnosti Filozofskog fakulteta Sveučilišta u Zagrebu, 69-78.

DE PASQUALE, A. 2002. La tipographia in Piemonte nel XV secolo. Comba, R. i Comino, G. (ur.) I protagonisti e le edizioni. Dal manoscritto al libro a stampa nel Piemon- 
te sud-occidentale (secoli XIII-XVI). Cuneo: Società per gli Studi storici, archeologici ed artistici della Provincia di Cuneo, 79-104.

DELAISSÉ, L. M. J. 1974. The importance of Books of Hours for the History of the Medieval Book. McCracken, U., Randall, L.M.C., Randal, R. H. Jr. (ur.) Gatherings in Honor of Dorothy E. Miner. Baltimore: The Walters Art Gallery, 203-226.

DELLA SANTA, G. 1915. Il tipografo dalmata Bonino de Boninis »confidente« della Repubblica di Venezia decano della cattedrale di Treviso (a. 1454-1528). Nuovo Archivio veneto 30: 174-206.

DEŠIĆ, N. 1995. Raj duše, faksimilni pretisak izdanja iz 1560. Rijeka: Franjevački samostan Trsat, Grad Rijeka.

DITTRICH, S. i L. 2004. Lexikon der Tiersymbole. Tiere als Sinnbilder in der Malerei des 14. - 17. Jahrhunderts. Petersberg: Michael Imhof Verlag.

DONDI, C. 2016. Printed Books of Hours from Fifteenth-Century Italy. The Texts, the Books, and the Survival of a Long-Lasting Genre. Firenca: Leo S. Olschki.

FUČIĆ, B. 1963. Istarske freske. Zagreb: Zora.

FREEDBERG, D. 1989. The power of Images. Studies in the History and Theory of Response, Chicago, London: The University of Chicago Press.

GOFF, F. R. 1988. The Factotum Initials of Petrus Liechtenstein at Venice. Ursula E. McCracken, Lilian M. C. Randall (ur .) Gatherings in Honor of Dorothy E. Miner. The Walters Art Gallery Baltimore, 241-255.

GÜLTLINGEN VON, S. 1992. Bibliographie des livres imprimés à Lyon au seizième siècle. Baden-Baden \& Bouxwiller: Valentin Koerner.

HAMM, B., 2010. Der Weg zum Himmel und die nahe Gnade. Neue Formen der spätmittelalterlichen Frömmigkeit am Beispiel Ulms und des Mediums Einblattdruck.

HASCHER-BURGER, U., DEN HOLLANDER, A., JANSE, W. (ur.) Between lay piety and learned theology: Studies presented to Christoph Burger on occassion of his 65th birthday. Leiden, Boston: Brill, 453-496.

HARTHAN, J. P. 1977. Books of Hours and Their Owners. London: Thames and Hudson.

Indice generale degli incunabuli delle biblioteche d'Italia. Roma: Istituto Poligrafico dello Stato 1943. - 1981.

HIND, A. M. 1963. An introduction to a history of woodcut. With a detailed survey of work done in the fifteenth century. Unabridged and unaltered republ. of the work first publ. in 1935, New York, NY : Dover Publ.

ISTC = Incunabula Short Title Catalogue, URL: https://data.cerl.org/istc/_search. (7. 11. 2019.)

JURIĆ, Š. 1993. Dobrić Dobrićević. Hrvatski biografski leksikon, sv. 3, Zagreb: Leksikografski zavod Miroslav Krleža, 430-432. (URL: http://hbl.lzmk.hr/clanak. aspx?id=4935; 16. 4. 2019.)

KOSIĆ, I. 1998. Dragocjena prinova u riznici Nacionalne i sveučilišne knjižnice u Zagrebu. Kolo 2: 62-78.

KRISTELLER, P. O. 1921. Kupferstich und Holzschnitt in vier Jahrhunderten. Berlin: Bruno Cassirer. 
LACOMBE, P. 1907. Livres d'heures imprimes au 15. et au 16. siecle: conserves dans les bibliothéques publiques de Paris. Paris: Imprimerie nationale.

MANZARI, F. 2016. Book of hours. Hamburger, J., Stoneman, W.P., Eze, A-M., e. a. (ur.) Beyond Words. Illuminated Manuscripts in Boston Collections. McMullen Museum of Art, Boston College, 288.

Metalcut $=$ URL: https://en.wikipedia.org/wiki/Metalcut. (8. 11. 2019.)

MILOŠEVIĆ, M. 1994. Andrija Paltašić Kotoranin. Cetinje: Matica crnogorska.

MOKROVIĆ, LJ. 2013. Volto santo u hrvatskim glagoljskim misalima i njegovi ikonografski izvori. Slovo 63: 83-140.

NETTEKOVEN, I. 2004. Der Meister der Apokalypsenrose der Sainte-Chapelle und die Pariser Buchkunst um 1500. Turnhout: Brepols.

NEEDHAM, P. 1998. Venetian printers and publishers in the fifteenth century. La Bibliofilia, 100, 157-200.

PANTELIĆ, M. 1981. Senjski Lobkowiczov glagoljski kodeks iz 1359. - Prototip srednjevjekovnih »Liber horarum« za laike. Senjski zbornik 8(1): 355-368.

PELC, M. 2000. Ilustracije u tiskopisima Dobrića Dobrićevića. Radovi Instituta za povijest umjetnosti 24: 135-154.

POZZA, N. 1983. L'editoria veneziana da Giovanni da Spira ad Aldo Manuzio. La stampa degli inconaboli nel Veneto. Venezia: Università internazionale dell'arte.

PRIJATELJ-PAVIČIĆ, I. 2011. Prilog poznavanju dubrovačkih molitvenika XV. stoljeća. Prilozi povijesti umjetnosti u Dalmaciji 42: 205-249.

PETRELLA, G. 2010. Gli incunaboli della Biblioteca del Seminario Patriarcale di Venezia. Catalogo, Venecija: Marcianum Press.

SANDER, M. 1942. - 1943. Le livre a figures Italien depuis 1476 jusqu'à 1530. Vol. 6. Milano: Hoepli.

TANDARIĆ, J. 1981. Hrvatski marijanski oficiji. Advocata Croatiae. Zagreb: 107-111.

TONIOLO, F. 2008. Gli incunaboli miniati della Biblioteca del Seminario vescovile: saggio critico e descrizione delle miniature. L. Armstrong, P. Scapecchi, F. Toniolo (ur.), Incunaboli della Biblioteca del Seminario vescovile di Padova. Padova: Istituto per la storia ecclesiastica padovana.

VALENTINELLI, G. 1870. Libri membranacei a stampa della Biblioteca Marciana di Venezia. Venezia: Tipographia del Commercio di Marco Visentini.

VENEZIANI, P. 1986. La tipografia a Brescia nel XV secolo. Firenze: Olschki.

WIECK, R. 1988. Time sanctified. The Book of Hours in Medieval Art and Life. New York: George Braziller and The Walters Art Gallery. 


\section{Summary}

\section{Milan PELC}

\section{PRINTED BOOKS OF HOURS OF ANDRIJA PALTAŠIĆ AND DOBRIĆ DOBRIĆEVIĆ (BONINUS DE BONINIS) AND THEIR ILLUSTRATIONS}

Two printers of Croatian origin, Andrija Paltašić in Venice and Dobrić Dobrićević (Boninus de Boninis) in Verona, were among the first to publish printed editions of the Office of the Blessed Virgin Mary: Paltašić 1478, Dobrićević 1481. Dobrićević's edition is the first known woodcutillustrated edition of printed book of hours. Later on, he published three more illustrated editions of Virgin Mary's Office in Lyon. This makes his contributions to the history of books of hours printing more significant than those by Paltašić. Dobričević's four office editions (1481, two in 1499, and one in 1501) consistently reflect the Italian and French traditions in terms of their content, iconography and visual art. The Verona edition is in complete correspondence with the Italian tradition, while the French tradition is reflected in his Lyon editions. The breviaries modelled on the French tradition are more extensive in their content compared to the Italian ones. They contain a larger number of New Testament texts and accompanying illustrations from the lives of Jesus and Mary. This makes the artistic, iconographic and decorative value of the French editions much more significant than that of the Italian editions. In this paper special attention is given to a copy of Dobričević's Office from 20 March 1499, printed on parchment, which originates from Emmanuele Cicogna's collection and is currently kept in the Museo Correr Library in Venice. Seeing as the copy had been damaged, Cicogna (according to his own handwritten notes on the inside cover) added pages and images from another copy of the same edition printed on paper, which is currently kept in fragments in the National Library of St Mark's in Venice. The parchment copy from Cicogna's collection provides a unique testimony of the interactive relationship between office users and its illustrations. Notably, some of the images have been partially erased due to frequent touching and, presumably, devout kissing. The most worn out pages are the ones containing the most popular prayers to the Madonna: Obsecro te and O intemerata, which contain an image of Mary with baby Jesus in her lap; a page containing a depiction of the Crucifixion on Golgotha; and one containing an illustration of Saint Apollonia, the patron saint of those suffering from toothache. Additionally, the figure of Satan was systematically erased in images depicting the Temptation of Christ. In this way, the devout user could express his anger against the tempter, just as unsophisticated observes in churches did by defacing his images in frescoes or covering them in derogatory words. Thus, Cicogna's damaged and supplemented copy points to the forms of practical devotion that the Office was used for.

Keywords: Dobrić Dobrićević (Boninus de Boninis), Andrija Paltašić, Nicolaus Jenson, Illustrations of the Office of Blessed Virgin Mary

Milan Pelc

Institute of Art History

Zagreb (Croatia)

mpelc@ipu.hr 